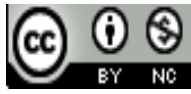 \\ Jurnal Terapan Manajemen dan Bisnis is licensed under \\ A Creative Commons Attribution-Non_Commercial 4.0 International License
}

\title{
Factors Affecting Students' Decisions Choosing SMA Maitreyawira Batam
}

\author{
Emi Lestari \\ Universitas Universal, Batam, Indonesia \\ E-mail: emicheerful98@gmail.com
}

\begin{abstract}
This study examines the quality of service that includes variable Reliability, Responsiveness, Assurance, Empathy and Evidence Direct (Tangible) partially and simultaneously affect the decision of students to choose SMA Maitreyawira Batam. The method of multiple regression analysis used by the researcher is to know and examine how big influence of independent variable which numbers two or more. Multiple regression analysis is used to know the influence of independent variables on dependent variable. The number of samples of this research is 110 students of SMA Maitreyawira Batam. The result of the research shows that there is significant influence of service quality with variable of reliability, responsiveness, assurance, empathy and tangible to student decision to choose SMA Maitreyawira Batam.
\end{abstract}

Keywords: quality of service, decision, reliability, guarantee.

\section{Introduction}

Education is the most important sector that becomes the root and principal of other sectors, because it is preceding this education that will print and prepare reliable cadres that are used and needed for other sectors either the product or service sector, through this education is also the one determining where the nation will be brought in, thus preparing a good and quality education container is a demand and absolute necessity for the cadres who are printed in accordance with the hope of creating a whole human being.

In Indonesia, the providers of educational containers have mushroomed both from remote villages to large cities, from high quality to mediocre quality, from the magnificent buildings to just a hovel. From the variety of both the quality and physical school that is offered by the manager of this education still, has one goal of the manager is to become the school of choice or favorite so as not to bother looking for students for the sake of survival (survive) a container. The continuity of an educational container is highly dependent on the number of students who attend school in addition to quality or other factors. Although not be denied probability a business is not only determined by the quantity or sales volume alone but long-term satisfaction for customers is the key determinant of profitability.

The most important characteristic in building a good relationship with the customer is by providing good service quality. Lewis and Booms (in Tjiptono, 2008: 85) define service quality as a measure of how well the level of service delivered is able to match customer expectations. Therefore, whether or not service quality depends on the service provider's ability to meet customer expectations consistently. By providing good service quality, the 
customer will depend on the party and the customer will have a commitment in the relationship so as to provide value for the company.

In order to become a school of choice the students of the provider of education need to pay attention to the quality of service, because the quality of good service will be an encouragement to the students to establish strong ties with the school, in this case, it will choose and be loyal to a school. Conversely, schools that fail to satisfy their students will face a complex problem where dissatisfied students will pass on their bad experiences to others if this happens will bring bad impacts and big losses to the school which will become a student shortage so that the target of profitability and survival will be difficult to achieve. Service quality measurements in the SERVQUAL model are based on multi-item scales designed to measure customer expectations and perceptions, and gaps between them in key service quality dimensions. In the original study, Parasuraman et al.1985 (in Tjiptono, 2014) identified ten key dimensions of reliability, responsiveness, competence, access, modesty, communication, credibility, religion, customer comprehension, and physical evidence. However, in the next study of these three experts (Parasuraman, et al., 1988) In Tjiptono, 2014 refine and embrace the ten dimensions.Competence, courtesy, credibility, and security are incorporated into assurance. While access, communication and the ability to understand customers categorized as empathy, thus there are five main dimensions (in the order of their relative importance degree), namely reliability, responsiveness, assurance, empathy and tangibles (Tjiptono, 2014)

Kotler and Armstrong (2008: 179) state that purchasing decisions are the result of a process consisting of five stages: recognition of needs, information retrieval, evaluation of factors, purchasing decisions, and post-purchase behavior. Reliability (reliability), namely the ability to provide services presented promptly, accurately, on time in accordance with the promised, and satisfactory (Wibisono, 2006: 95).

Reliability according to Parasuraman (2001) is that every employee has a reliable ability, know the ins and outs of working procedures, working mechanisms, correct any deficiencies or irregularities that are not in accordance with work procedures and able to show, direct and provide correct direction to every form of service has not been understood by society. So as to give a positive impact on the service.

Relation dimension of service reliability (reliability) is a very important in the dynamics of work of an organization. Reliability is a characteristic form or characteristics of employees who have high performance. Reliability in service delivery can be seen from the reliability of providing services in accordance with the level of knowledge possessed, reliability in skilled in the field of work applied, reliability in the mastery of work according to work experience shown and reliability using technology work. Sunyoto (2004: 16) the reliability of an individual organization in providing services is needed to face the motion of the dynamics of work continues to demand a high quality of service according to the reliability of individual employees. The reliability of an accomplished employee can be seen from:

1. Reliability in providing services in accordance with the level of knowledge of the description of work.

2. Reliability in providing skilled services in accordance with the level of skills they have in running an efficient and effective service activities.

3. Reliability in providing services in accordance with their work experience, so that the mastery of the description of work can be done quickly, precisely, easily and qualified according to his experience.

4. Reliability in applying technology mastery to obtain accurate and satisfactory service according to the output of the use of the technology shown. 
Reliability (reliability) according to Tjiptono (2014: 282) is the ability to provide services promised immediately, accurately, and satisfactorily. Reliable services (reliability) in an educational container is determined by the ability of managers in realizing service in accordance with the promised. Services performed in accordance with the promise indicate a good commitment from providers of education services in realizing student expectations. By always paying attention relevance between subjects with the tasks given as well as real practice so that students are not too charged and easy to understand where the direction of an education brought. If the provider of education services can carry out the services performed with the promise that has been given shows the performance of educational service providers are able to meet student expectations.

According to Kotler and Keller (2010) revealed that the responsiveness (responsibility) is the level of speed and accuracy provided by service personnel to customers. According to (Wibisono, 2006: 95) states that Responsibility (Responsibility) is describing the desire to help customers and provide services quickly and accurately.

Responsiveness (responsiveness) according to Tjiptono (2014: 282) is the desire of the staff to help the customers and provide services with responsiveness.

Responsiveness is a service expected by students, it is shown the resilience to help students in facing problems or complaints in learning, the resilience in handling new student enrollment, courtesy of educators and the education and ability of education service providers in instilling trust in students is a component of service expected by students so that if it can be implemented well and tangible will make the school of student choice.

According to (Margareta, 2003) Guarantees for services provided by employees are largely determined by performance or service performance, so it is believed that the employee is able to provide reliable, independent and professional services that impact on the satisfaction of the service received. Aside from that performance, the assurance of a service is also determined by strong organizational commitment, which encourages each employee to give serious and serious service to satisfy the person served. Another form of assurance is the assurance of employees who have a personality behavior (personality behavior) is good in providing services, would be different employees who have good character or character and that is less good in providing services. A work organization desperately needs a trust that is believed to be in accordance with the fact that the organization is able to provide quality services that can be guaranteed in accordance with:

1. Able to provide satisfaction in the service that every employee will provide a fast, precise, easy, smooth and quality service, and it becomes a concrete form that satisfies the people who get the service.

2. Able to demonstrate high work commitment in accordance with the forms of work integrity, work ethic and work culture in accordance with the application of the vision, mission of an organization in providing services.

3. Able to provide assurance of service in accordance with the behavior shown, so that people who get the service sure in accordance with the behavior he saw.

According to Kotler and Keller (2010) express assurance (assurance) as a guarantee given to customers to get the best service. According to (Dermawan Wibisono, ph.D., 2006: 95) Assurance is about the designated combination of competence, trust, accuracy of handling and security. Assurance by Tjiptono (2014: 282), includes knowledge, competence, courtesy, and credibility of staff, from harm, risk or doubt.

With the assurance (assurance) of educators and educational reliable in the field which means there is a good placement of workers both educators and educational staff in accordance with educational background, expertise, and experience owned so as to provide good and competent service. An educational container is also indispensable for guaranteeing 
the reputation of a good and fragrant school, educators and educational staff who are able to instill the value of modesty towards their students, create a sense of security and comfort in the school environment and provide a consistency between the cost of education with the quality and facilities received students, so that it will arise students' confidence to make the school into the school of choice.

According to Kotler and Keller (2010) revealed that empathy (empathy) as the attention given to each individual customer. According to (philanthropist Wibisono, ph.D., 2006: 95) Empathy involves the combination of various types of services designed to include the fulfillment, communication, and understanding of the customer's public which is intended to pay attention to the customer. Empathy according to Tjiptono (2014: 282) includes the ease of establishing relationships, good communication, personal attention and understanding of the individual needs of customers.

The importance of an educational container to create empathy for students is by creating ease of students to contact the school when necessary, provide information to students with the media and easy way to understand by students so that the information provided can be implemented and useful for students, always listening patiently complaints and suggestions from students in order to establish a good reciprocal relationship between students with educators and existing education in school and educators are expected to be able to understand carefully the needs of students. With the service of empathy of an educational container will undoubtedly make the school into the school of choice for students.

Tangible evidence is a form of actual actualization physically visible or used by an employee in accordance with its use and utilization which can be felt to help the service received by the person who wants the service, thereby satisfying the perceived service, which also shows the performance of the service delivery (Parasuraman, 2001: 32). According to Kotler and Keller (2010), Direct evidence (tangible) is a concrete manifestation of the services provided by service personnel. Tangible for a consumer can only be felt. According to Philanthropist (Wibisono, 2006: 95), Tangible is about visible organizational facilities, equipment available to customers. Physical evidence (tangibles) according to Tjiptono (2014: 282) includes facilities, equipment, employees, and means of communication.

Physical forms (tangibles) such as buildings, instructional equipment, libraries, laboratories, communication facilities and ranks of educators and adequate education is a tangible form. Students will feel satisfied if the place where he obtained educational services attractive, complete and comfortable. In the first time, consumers will see the physical appearance of a service provider. This will give them an idea that a service provider will provide quality services that will make the school of choice of students and remain loyal to the educational container that has become his choice.

The Maitreyawira School of Batam is one of the educational institutions under the auspices of the Panacaran Maitri Foundation, which was established in 2004 which currently houses the Kindergarten (KBTK), Primary School (SD), Junior High School (Sekolah Menengah Pertama) Junior High School), Senior High School (SMA) and Vocational High School (SMK). With student data in Table 1.

Maitreyawira Batam student admissions data above shows that during the 5-year interval between 2010/2011 and 2014/2015, the growth rate of senior high school graders is very slow and tends to decrease when compared to other levels except for the secondary school level Vocational (SMK) is not a comparison here because SMK is a new level open for this year's teachings 2014/2015. The above data gives an illustration, there is a problem about student's interest to enroll in high school level (SMA) Maitreyawira Batam. Departing from this problem the authors feel the need to examine "Factors influencing the decision of 
students choose SMA Maitreyawira Batam". Because since the establishment of this school the high school level has never reached the quota of new admissions according to the specified target. By knowing the main factors that become the student's choice in determining the choice of school, it is expected that the manager can emphasize the values that become the consideration of the students so that the achievement of the student acceptance quota can reach the target that has been determined.

\section{Research Method}

Types of research

This research uses quantitative approach. Based on data collection techniques and information, in this study using two kinds of data that is primary data and secondary data. Primary data were obtained by questionnaire list through field survey while secondary data was obtained from Maitreyawira School administration data.

This research is an associative research, that is research connecting two or more variables (Ginting and Situmorang, 2008: 57). Therefore, this research will explain the influence of service quality that includes the factors that consist of reliability (reliability) (X1), responsiveness (X2), assurance (X3), empathy $(\mathrm{X} 4)$, and physical evidence (tangibles) (X5) on the decision to vote $(\mathrm{Y})$ at SMA Maitreyawira Batam

Population

The population of this study is all students of senior high school (SMA) Maitreyawira Batam, where based on administrative data for the school year 2014/2015 the number of high school students Maitreyawira School is as follows:

Class $10=74$ students

Grade $11=89$ students

Class $12=60$ students

So the total number of students or the number of the study population is 223 students. Sample

In this study, the sample is some high school students Maitreyawira. Based on the calculation of sample size that has been done obtained the number of sample sizes amounted to approximately 110 students of respondents. The sampling technique according to (Syofian Siregar, 2013: 31) by the proportional method of the sample where the samples were taken from each stratum is proportional, in accordance with the proportional size. Then the determination of sample based on the above data is as follows:

Population $=223$ students

Sample size $=110$ students

Proportion of samples for each class $=110 / 223=0.49$

Analysis Technique

This research consists of 6 variable that is service quality variable which includes: reliability, responsiveness, assurance, empathy, tangible and decision variable choose High School (SMA) Maitreyawira Batam.

Independent variable

In this study the independent variables are as follows:

1. Reliability (Reliability) X1

The indicators of reliability are as follows:

a. Provide learning accurately.

b. Providing the best service as expected

c. Teachers and educators who are reliable and skilled in teaching and providing services.

d. Treating students fairly. 
2. Responsibility (Responsiveness) $\mathrm{X} 2$

Responsiveness indicators in this research are:

a. Fast handling for new students

b. Quick response to student complaints

c. Friendly and courteous in providing service

d. Able to instill trust in students

3. Assurance (Security) X3

Assurance by Tjiptono (2014: 282), includes knowledge, competence, credence, and credibility of staff, from harm, risk or doubt. (Parasuraman, et. Al., 1988) In (Tjiptono 2014: 282) incorporates the guarantees dimension of the competence of civility, credibility, and security with the following dimensions and indicators:

a. Competence: the mastery of skills and knowledge needed to provide the required services. Indicator of competence in this research is: educator and educational staff have a good knowledge and competent capacity.

b. Courtesy: courtesy, respect, attention, and friendliness of the frontline staff. Indicators of decency in this study are: Educators and admin staff can apply ethical values to the students.

c. Credibility: honest and credible attitude. The credibility indicators in this study are: SMA Maitreyawira has a good reputation.

d. Security: free of danger, risk, or doubt. Security indicators in this study are: can create a safe and comfortable atmosphere.

4. Empathy $\mathrm{X} 4$

Parasuraman, et, al., (1988) in (Tjiptono 2014: 282) combines the empathy dimension of access dimensions, communication, and the ability to understand the customer. With the following dimensions and indicators:

a. Access: easy to contact and meet. The indicator of access in this study is: easy to contact the school.

b. Communication: provide information to customers in a language they can understand, and always listen to their suggestions and complaints. Communication indicators in this research are; information is notified with clear language, willing to listen to patient complaints and suggestions patiently.

c. The ability to understand customers: trying to understand their customers and needs. Indicator ability to understand customer in this research is: able to understand student requirement.

5. Tangible (Direct Evidence) X5

The tangible indicators in this study are as follows:

a. Adequate learning facilities

b. Condition of equipment and room is adequate

c. The number of teachers and administrative staff is adequate

d. The means of communication are adequate

Dependent Variables

The dependent variable (Dependent Variable) is given the symbol Y

The dependent variable in this research is the decision to choose SMA Maitreyawira

Batam. These goals are largely determined by service quality, multidimensional strategies and product adoption including:

1. Meeting the needs of the product

2. Activeness in finding products,

3. Conscious Consciousness

4. The right decision. 
A behavior or response to the activity of an object. As an indicator of the decision to vote is as follows:

1. Schools that suit your needs

2. Continue to the next level and level at Maitreyawira

3. Schools chose consciously

4. Have made the right decision in choosing school

From Indicator can be made question through questionnaire and through answer of questionnaire is taken average value for each indicator. The indicator of the above variable is used to construct the questionnaire instrument or questionnaire by scoring the Likert Scale filled by the respondent.

Resources and Data Collection Methods

In this study the data obtained is the data sourced from the primary data and secondary data with the following conditions:

1. Primary Data

Namely, the data obtained directly from the respondents in the form of questionnaires or distributed to high school students Maitreyawira as a sample of research and observation of the phenomenon under study. The distributed questionnaire is designed in multiple-choice by Likert scale.

2. Secondary Data

Namely the data in the form of school history, number of students and the number of new admissions from Maitreyawira Batam school obtained from the archives / documentation stored in the administration / personnel from the level of each school and in the system / software online that can be accessed by parties which is authorized in the foundation one of which is the Accounting and Finance department. Data collection is done by direct access to the system online / software students associated with the object of research.

Data Analysis

1. Selection and Input Data

The total questionnaires distributed to the students of each class over 5 questionnaires of the required amount, this is to anticipate any questionnaires that are not returned or damaged. Questionnaires data that has been filled and returned by the respondent checked the completeness of the filling, sorted, inputted and classified into the tabulation of data, from the results of the questionnaire obtained each class is a class 10 of 36 sets, class 11 a 44 sets and class 12 of 30 sets with the overall total is as many as 110 sets.

2. Analysis Description Characteristics of Respondents and Variables

The descriptive analysis aims to convert the raw data set into easy to understand in the form of more concise information. In research using a value that tends to be a central value that represents an observation. In descriptive analysis, this value can be represented by mean (average) and mode.

Mean is the average value of the result of observation on a variable and is the sum of all observation results divided by the amount of observation.

Mean is formulated as $x=\Sigma x / n$, (Istijanto, 2005: 95).

Information:

$x$ is the average value of observation

$\Sigma x$ means the sum of all observations

$\mathrm{N}$ is the number of observations.

The degree of tendency is modified into 4 categories with the following categorization range terms:

a. Very Good, if $3.5 \leq \mathrm{x} \leq 4$ 
b. Good, if $2.5 \leq x<3.5$

c. Bad, if $1.5 \leq x<2.5$

d. Very bad, if $1 \leq \mathrm{X}<1.5$

The model describes the frequency value that most often appears or has the highest frequency (Istijanto, 2005: 96). In this case, the respondents' answers will be grouped based on variables and indicators of each item question.

3. Test the research instrument

a. Test Validity

In this section, the validity of the instrument being tested is the validity of the construct (construct validity). Test the validity using correlation coefficient calculation technique that will assess how big the correlation between the score of each item question in the questionnaire with the total score obtained by each variable.

b. Test Reliability

In this research instrument reliability testing using internal consistency method which means that test is done only once. Reliability testing is done with the help of SPSS 21 software which will calculate Alpha-Cronbach reliability coefficient. The criterion of an instrument is considered to be reliability if the reliability coefficient value is at least 0.7 or higher (Fraenkel \& Wallen, 1993: 149).

4. Classical Assumptions

The classical assumption test is performed to allow unbiased estimates, before performing multiple linear regression analysis, the criteria of classical assumption requirements that must be met:

a. Test. Normality

Normality testing is done by the Kolmogorov-Smirnov Test method or visually detecting Q-Q plots. This test is performed with the help of SPSS 21 software. The criteria used are if the probability value obtained from the SPSS output is greater than the significance level (sig> 0.05) then the data of the normally distributed variable or if the data visualization results on the QQ plot are around the line normal (Field, 2009: 147).

b. Linearity Test

This test is done by the test for linearity method with the help of SPSS 21 software. The criterion used is if the probability value obtained from the linearity of SPSS output is smaller than the level of significance $(\mathrm{sig}<0,05)$, the relationship between independent variable to dependent variable is linear (Duwi Priyatno, 2010: 46).

c. Heteroscedasticity Test

Detection of heteroscedasticity is done Spearman's rho method with the help of SPSS 21. The criterion used is if the probability value obtained in the Unstandardized Residual Residual SPSS output is greater than the significance level (sig> 0.05) then there is no heteroscedasticity problem (Duwi Priyatno, 2010: 71).

d. Test of Multicollinearity

To find out whether there are any symptoms of multicollinearity can be seen from the amount of tolerance and VIF (Variance Inflation Factor) through the SPSS program. Tolerance measures variability of selected variables that are not explained by other independent variables. The criterion used is if the value of VIF $<10$ at SPSS output hence no multicollinearity is stated. (Field, 2009: 224)

e. Multiple Linear Regression Analysis

The method of multiple regression analysis used by the researcher is to know and examine how big influence of independent variable which numbers two or more. 
To get more directional results, researchers used SPSS 21.00 for windows. The equation model used is:

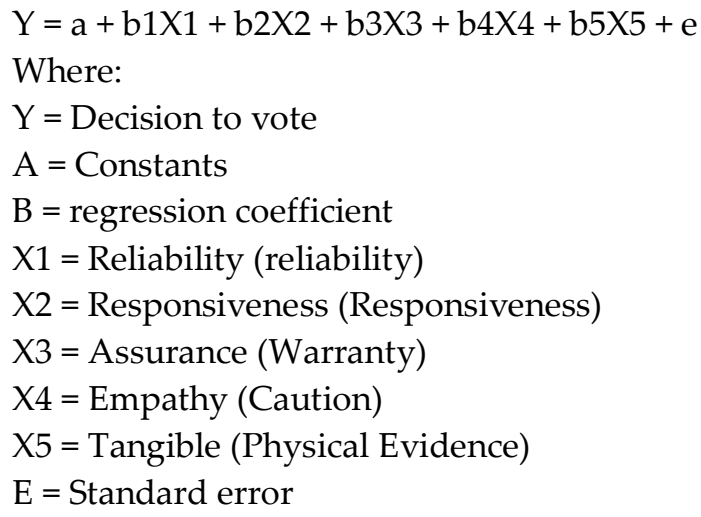

Hypothesis testing

1. Partial Significant Test (t-Test)

This test is performed to view individually or partially from each independent variable $(\mathrm{X})$ to the dependent variable $(\mathrm{Y})$ whether there is a significant influence. Criteria for decision making are:

$\mathrm{H} 0$ accepted if $\mathrm{t}$ count $<\mathrm{t}$ table at $=5 \%$

$\mathrm{H} 0$ rejected if $\mathrm{t}$ count $>\mathrm{t}$ table at $=5 \%$

2. The dominant free variable

This test is conducted to see among the independent variables consisting of the variables reliability, responsiveness, assurance, empathy and tangible the most dominant influence significantly to the dependent variable is the student chooses to vote.

Criteria of decision-making are the independent variable that has the value of regression coefficient (B) and $t$ arithmetic largest with a value of significance $<0.05$.

3. Simultaneous Significant Test (F Test)

This test is performed to see if all the independent variables included in the model have a simultaneous effect on the dependent variable.

Criteria for decision-making are:

a. If the probability value of 0.05 is smaller or equal to the sig probability value, then $\mathrm{H} 0$ is accepted and Ha is rejected, that is not significant.

b. If the probability value of 0.05 is greater than or equal to the sig probability value, then $\mathrm{HO}$ is rejected and $\mathrm{Ha}$ is accepted, meaning significant.

\section{Results Analysis Of Research And Discussion}

1. Research data

The subjects of this research are students who attend school at Maitreyawira Senior High School which is managed by Yayasan Pancaran Maitri, located in Batam city, Riau Islands.

Research data based on each characteristic can be seen as follows:

a. Research Data Based on Sex

Maitreyawira Batam senior high school students in the respondents by sex are male 49 students and female 51 students. From the data can be concluded the respondent with female gender is more dominant.

b. Research Data Based on Class.

The students of SMA Maitreyawira Batam in the respondents based on the class are 10th grade students amounted to 36 students, 11th graders amounted to 44 students, and 12th graders amounted to 30 students. From the above data, it can be concluded 
the respondent of the 11th grade is more dominant, while the least respondent is from class 12.

2. Analysis of Research Results

Description of Research Variables

Description of research variables aims to determine the responses of respondents about the indicators of the variable reliability (X1), responsiveness $(\mathrm{X} 2)$, assurance $(\mathrm{X} 3)$, Empathy (X4), Tangible (X5) and the decision to choose (Y) each of the indicators that make up the research variables are as follows:

a. Description of variable reliability

Reliability is the reliability of the educational staff and the education of SMA Maitreyawira is included in the good category (average score 2,468), which is shown by educators to provide accurate learning, provide good service as expected by students, reliable and skilled in teaching and providing services, and treats students fairly.

Respondents' response to variable reliability is as follows:

1) The first indicator is to provide learning accurately, who answered strongly disagree as much as $17 \%$, disagree as much as $27 \%$, agree $52 \%$ and strongly agree $4 \%$. It can be concluded that the most responses are the agreed responses while the least responses are the strongly disagreeable responses.

2) The second indicator is to provide the best service as expected, who answered strongly disagree as much as $29 \%$, disagree as much as $35 \%$, agree $31 \%$ and strongly agree $5 \%$. It can be concluded that the most responses are disagreeable responses while the fewest responses are strongly agreed.

3) The third indicator that is reliable and skilled in teaching and providing services, who answered strongly disagree as much as $5 \%$, disagree as much as $35 \%$, agree $55 \%$ and strongly agree $5 \%$. It can be concluded that the most responses are the agreed response while the fewest responses are strongly agreed.

4) The fourth indicator is to treat students fairly, who answered strongly disagree as much as $5 \%$, disagree as much as $26 \%$, agree $56 \%$ and strongly agree $13 \%$. It can be concluded that the most responses are the agreed responses while the least responses are the strongly disagreeable responses.

b. Description of responsiveness variable

The average value of responsiveness of 2,436 indicates that responsiveness by educators and education is poor (average score 2,436) indicated in the handling of new students quickly, responsiveness to student complaints, friendly and courteous in providing services and able to inculcate trust to students.

Respondents' responses to responsiveness variables are as follows:

1) The first indicator of fast handling for new students, who answered strongly disagree as much as $12 \%$, disagree as much as $32 \%$, agree $53 \%$ and strongly agree $3 \%$. It can be concluded that the most responses are the agreed response while the fewest responses are strongly agreed.

2) The second indicator is quick response to the complaints of students, who answered strongly disagree as much as $14 \%$, disagree as much as $38 \%$, agree $44 \%$ and strongly agree $4 \%$. It can be concluded that the most responses are disagreeable responses while the fewest responses are strongly agreed.

3) The third indicator is friendly and polite in providing services, who answered strongly disagree as much as $10 \%$, disagree as much as $37 \%$, agree $48 \%$ and strongly agree $5 \%$. It can be concluded that the most responses are the agreed response while the fewest responses are strongly agreed. 
4) The fourth indicator is able to instill trust in students, who answered strongly disagree as much as $13 \%$, disagree as much as $35 \%$, agree $48 \%$ and strongly agree $4 \%$. It can be concluded that the most responses are the agreed response while the fewest responses are strongly agreed.

c. Description of assurance variables

The average value of the assurance variables is 2,450 included in the good category (average score 2,450), it is shown that educators and educators have a good and competent knowledge capacity, always instilling ethical values to the students, and can create a safe atmosphere and comfortable and SMA Maitreyawira has a good reputation.

Respondents' responses to assurance variables are as follows:

1) The first indicator is to have a good knowledge capacity and competent, who answered strongly disagree as much as $12 \%$, disagree as much as $30 \%$, agree $55 \%$ and strongly agree $3 \%$. It can be concluded that the most responses are the agreed response while the fewest responses are strongly agreed.

2) The second indicator is applying the values of ethics to students, who answered strongly disagree as much as $14 \%$, disagree as much as $36 \%$, agree $46 \%$ and strongly agree $4 \%$. It can be concluded that the most responses are the agreed response while the fewest responses are strongly agreed.

3) The third indicator that has a good reputation, who answered strongly disagree as much as $10 \%$, disagree as much as $37 \%$, agree $47 \%$ and strongly agree $6 \%$. It can be concluded that the most responses are the agreed response while the fewest responses are strongly agreed.

4) The fourth indicator that can create a safe and comfortable atmosphere, who answered strongly disagree as much as $13 \%$, disagree as much as $35 \%$, agree $49 \%$ and strongly agree $3 \%$. It can be concluded that the most responses are the agreed response while the fewest responses are strongly agreed.

d. Description of mean value of empathy variable

The average of empathy from SMA Maitreyawira is good (average score 2,450 ), indicated by creating easiness to contact the school, providing information of the patient with clear and easy to understand language, willing to listen to patient's complaints and suggestions patiently and able to understand the need students.

The response of respondents to empathy variable is as follows:

1) The first indicator is easy to contact the school, who answered strongly disagree as much as $6 \%$, disagree as much as $31 \%$, agree $57 \%$ and strongly agree $5 \%$. It can be concluded that the most responses are the agreed response while the fewest responses are strongly agreed.

2) The second indicator is to provide information clearly, who answered strongly disagree as much as $7 \%$, disagree as much as $31 \%$, agree $55 \%$ and strongly agree $7 \%$. It can be concluded that the most responses are disagreeable responses while the least responses are very agreeable and strongly disagree.

3) The third indicator is listening to patient complaints and suggestions patiently, who answered strongly disagree as much as $22 \%$, disagree as much as $31 \%$, agree $41 \%$ and strongly agree $6 \%$. It can be concluded that the most responses are the agreed response while the fewest responses are strongly agreed.

4) The fourth indicator is able to understand the needs of students, who answered strongly disagree as much as $18 \%$, do not agree as much as $45 \%$, agree $32 \%$ and strongly agree $5 \%$. It can be concluded that the most responses are disagreeable responses while the fewest responses are strongly agreed. 
e. Description of tangible variables

The average value for the Tangible 2.452 variable is either good (average value 2,452), it is shown by SMA Maitreyawira peppering learning facilities, equipment conditions, number of educators and education and communication facilities.

Respondents to tangible variables are as follows:

1) The first indicator is adequate learning facilities, which answered strongly disagree as much as $17 \%$, disagree as much as $28 \%$, agree $50 \%$ and strongly agree $5 \%$. It can be concluded that the most responses are the agreed response while the fewest responses are strongly agreed.

2) The second indicator is the condition of equipment and adequate room, which answered strongly disagree as much as $28 \%$, disagree as much as $37 \%$, agree $30 \%$ and strongly agree $5 \%$. It can be concluded that the most responses are disagreeable responses while the fewest responses are strongly agreed.

3) The third indicator is the number of teachers and administrative staff is adequate, who answered strongly disagree as much as $5 \%$, disagree as much as $35 \%$, agree $55 \%$ and strongly agree $5 \%$. It can be concluded that the most responses are the agreed response while the fewest responses are strongly agreed.

4) The fourth indicator of adequate means of communication, which answered strongly disagree as much as $8 \%$, disagree as much as $25 \%$, agree $58 \%$ and strongly agree $9 \%$. It can be concluded that the most responses are disagreeable responses while the fewest responses are strongly agreed.

f. Description of decision variable to choose

The quality of services provided by SMA Maitreyawira is good (average $2,516)$ by creating a school that matches the needs of the students so that students continue to vote and be loyal to SMA Maitreyawira and the next level, the school of choice for the students personally and consciously as well as the students will still feel have made the right decision in choosing SMA Maitreyawira Batam.

Respondents to tangible variables are as follows:

1) The first indicator of the school as needed, who answered strongly disagree as much as $24 \%$, disagree as much as $32 \%$, agree $39 \%$ and strongly agree $5 \%$. It can be concluded that the most responses are the agreed response while the fewest responses are strongly agreed.

2) The second indicator is to continue the gap and the next level in Maitreyawira, who answered strongly disagree as much as $13 \%$, disagree as much as $37 \%$, agree $42 \%$ and strongly agree $8 \%$. It can be concluded that the most responses are disagreeable responses while the fewest responses are strongly agreed.

3) The third indicator is consciously chosen schools, which respond strongly disagree as much as $9 \%$, do not agree as much as $29 \%$, agree $54 \%$ and strongly agree $8 \%$. It can be concluded that the most responses are the agreed response while the fewest responses are strongly agreed.

4) The fourth indicator is the right decision in choosing a school, who answered strongly disagree as much as $2 \%$, disagree as much as $33 \%$, agree $55 \%$ and strongly agree $10 \%$. It can be concluded that the most responses are the disapproving responses while the least responses are the strongly disagreeable responses.

Validity Test Results and Instrument Reliability

In this research, validity and reliability test is to variable reliability (X1),

Responsiveness (X2), Assurance (X3), Empathy (X4), Tangible (X5) and decision of 
choosing ( $\mathrm{Y})$, measuring instrument used is in the form of questionnaire on the questionnaire, which consists of items or items of questions prepared to obtain data variables.

a. Test Validity

From the result of the summary of the validity test the significance value for the correlation coefficient between each item is greater than the specified significance level $(\alpha)$ is 0.05 or indicated by the sign * or ${ }^{* *}$ so it can be concluded that each item questions each variable in this study is valid.

b. Test Reliability

The coefficient value for the Reliability variable is 0.787 ; coefficient value for Responsiveness variable is 0.764 ; coefficient value for assurance variable is 0.766 ; the coefficient value for the Empathy variable is 0.784 ; and coefficient value for Tangible variable is 0.789; and coefficient value for Decision Select variable is 0805, which all variables greater than 0.7 so it can be concluded that each instrument of this research variable is reliable.

c. Classic Assumption Test

A good regression model is that there is no bias or no classical assumption problem in the model. The classical assumption test is as follows:

The sig value of the SPSS output for Reliability (Reliability) variable is 0,550 ; sig value for variable Responsiveness (Responsiveness) is 0,154; the sig value for the Assurance variable is 0.164; the sig value for the Empathy variable (Empathy) is 0.151; the sig value for the Tangible variable (Physical Evidence) is 0.096 and the sig for Decision Selection variable is 0.112 . The visualization results of $Q-Q$ plots for each variable also show that the relative data is in the vicinity of the normal line. This means that all variables are normally distributed.

The test of linearity between each independent variable (Reliability, Responsiveness, Assurance, Empathy, Tangible) and dependent variable (Decision of Select) all yield sig value below 0,05 so it can be concluded that the relation between Reliability variable and Decision Select variable is declared linear, the relationship between Responsiveness variable and Decision Selection variable is declared linear, the relationship between Assurance variable and Decision Selection variable is declared linear, the relationship between Empathy variables and Decision Select variable is declared linear, and the relationship between Tangible variable and Decision select variable is declared linear.

The sig value for the Reliability variable is 0.728 ; the sig value for Responsiveness variable is 0.491 ; the sig value for the Assurance variable is 0.818 ; the sig value for the Empathy variable is 0.768 and the sig value for the Tangible variable is 0.706 ; all of which are worth more than 0.05 . This means that all variables do not have heteroscedasticity problems.

The VIF value for the Reliability variable is 1.059; the VIF value for the Responsiveness variable is 1.047; the VIF value for the Assurance variable is 1.195; the VIF value for the Empathy variable is 1.117 and the VIF value for the Tangible variable is 1.192; all of which are worth less than 10 which means no multicollinearity.

d. Multiple Linear Regression Analysis

The correlation coefficient can show how much influence of each independent variable to the dependent variable, and can know the influence of simultaneous and partial. The calculation result using SPSS 21.00 is shown in table 5.21 
Table 1 Results of Multiple Regression Calculations

\begin{tabular}{|l|l|l|l|}
\hline Variable & $\begin{array}{l}\text { Regression } \\
\text { Coefficient }\end{array}$ & Beta & Sig \\
\hline Reliability & 0,155 & 0,145 & 0,037 \\
\hline Responsivenness & 0,301 & 0,251 & 0,000 \\
\hline Assurance & 0,414 & 0,347 & 0,000 \\
\hline Emphaty & 0,232 & 0,214 & 0,003 \\
\hline Tangible & 0,361 & 0,341 & 0,000 \\
\hline $\begin{array}{l}\text { Constant =-4,272 } \\
\text { F statistics =24,408 }\end{array}$ & $\mathbf{R}^{2}$ & $=0,540$ \\
\hline
\end{tabular}

Based on the results of the linear regression calculation in Table 1 obtained the following equation:

$\mathrm{Y}=-4,272+0,155 \mathrm{X} 1+0,301 \mathrm{X} 2+0,414 \mathrm{X} 3+0,232 \mathrm{X} 4+0,361 \mathrm{X} 5$

1) Coefficient of Determination

The coefficient of determination of 0,540 indicates that the contribution of all independent variables to the decision to vote is $54 \%$, while the remaining $46 \%$ is influenced by other variables not mentioned in this research.

2) Regression coefficient

The obtained linear regression equation can be made clear as follows:

$\mathrm{Y}=-4,272+0,155 \mathrm{X} 1+0,301 \mathrm{X} 2+0,414 \mathrm{X} 3+0,232 \mathrm{X} 4+0,361 \mathrm{X} 5$

b0 $=-4,272$ means that if all independent variables do not change then the decision of student to choose equal to $-4,272$

a) $\mathrm{b} 1=0.155$ means that if the responses of respondents about the reliability rose by one unit of the score then the student's decision to vote for 0.155 units score

b) b2 $=0.301$ means if the responses of respondents about responsiveness rose by one unit score then the decision of students to vote for 0.301 units score

c) $b 3=0.414$ means that if the response respondents about Assurance rose by one unit score then the decision of students to vote for 0.414 units score

d) $\mathrm{b} 4=0.232$ means if the response of respondents about Empathy rose by one unit score then the student's decision to vote for 0.232 score unit

e) $\mathrm{b} 5=0.361$ means if the response of respondents about Tangible rise by one unit score then the student decision to vote for 0.361 units score

3) Beta Coefficients

To know the magnitude of the influence of each variable can be explained by the coefficient beta as follows:

a) $\beta 1=0,145$ means the effect of reliability to the student's decision to vote for $14.5 \%$.

b) $\beta 2=0.251$ means the influence of responsiveness to the student's decision to vote for $25.1 \%$.

c) $\beta 3=0.347$ means the influence of Assurance on the student's decision to vote for $34.7 \%$.

d) $\beta 4=0.214$ means the influence of empathy on the decision of the student to vote for $21.4 \%$.

e) $\quad \beta 5=0.341$ means tangible influence on students' decision to choose students of $34.1 \%$. 
Hypothesis Testing

This section will explain partial hypothesis testing, dominant and simultaneous variables

1. Hypothesis Testing by Partial (t-test)

The calculation result using SPSS 21.00 is shown in table 5.22

Table 2 Summary of Test Result Test $t$

\begin{tabular}{|l|l|l|c|}
\hline \multicolumn{1}{|c|}{ Variable } & $\begin{array}{l}\text { Regression } \\
\text { Coefficient }\end{array}$ & \multicolumn{1}{c|}{$\mathrm{t}$} & Sig \\
\hline Reliability & 0,155 & 2,114 & 0,037 \\
\hline Responsivenness & 0,301 & 3,688 & 0,000 \\
\hline Assurance & 0,414 & 4,776 & 0,000 \\
\hline Emphaty & 0,232 & 3,050 & 0,003 \\
\hline Tangible & 0,361 & 4,689 & 0,000 \\
\hline
\end{tabular}

The t-test results (Table 2) are as follows:

a. Hypothesis Test Effect of Reliability (X1) on Decision Selects.

The result of tstatistics of reliability variable obtained is 2,114 and result of ttable ( $\mathrm{df}$ residual 104) is 1,982 , so it can be seen that tstatistics $(2,114)>$ ttable $(1,982)$ and significant value $0,037<\alpha$ is 0,05 , hence can be concluded Ho rejected and H1 is accepted means reliability (X1) partially has a significant influence on the student's decision to vote.

b. Hypothesis Test of The Effect of Responsiveness (X2) on Decision Selects.

The result of tstatistics of responsiveness variable obtained is 3,688 and the result of ttable (df residual 104) is 1,982 , so it can be seen that tstatistics $(3,688)>$ ttable $(1,982)$ and significant value $0.000<\alpha$ is 0,05 , hence can be concluded Ho rejected and H1 is accepted means responsiveness (X2) partially has a significant influence on the student's decision to vote.

c. Hypothesis Test of The Effect of Assurance (X3) on Decision Selects

The result of the assurance variable is 4.776 and the result of ttable (df residual 104) is 1,982 , so it can be seen that tstatistics $(4,776)>$ ttable $(1,982)$ and significant value 0.000 $<\alpha$ is 0,05 , hence can be concluded Ho is rejected and H1 accepted means Assurance (X3) partially have a significant influence on the student's decision to vote.

d. Hypothesis Test of The Effect of Empathy (X4) on the Decision of Selecting.

The result of tribe empathy variable obtained is 3,050 and result from ttable ( $\mathrm{df}$ residual 104) is 1,982 , so it can be seen that tstatistics $(3.050)>(1,982)$ and significant value $0,003<\alpha$ is 0,05 , hence can be concluded Ho rejected and H1 accepted means empathy (X4) partially have a significant influence on decision of student choose.

e. Hypothesis Test of The Effect of Tangible (X5) on the Decision of Selecting

Result of tangible variable is 4,689 and result from ttable (df residual 104) is 1,982, so it can be seen that tstatistics $(4,689)>(1,982)$ and significant value $0.000<\alpha$ is 0,05 , hence can be concluded Ho rejected and H1 accepted means Tangible (X5) partially has a significant influence on the student's decision to vote.

2. Specifying Dominant Variables

From the calculation of $\mathrm{t}$ test as seen in table 5.22 can be seen that among variable reliability, responsiveness, assurance, empathy and tangible. Of the five variables assurance variable $(\mathrm{X} 3)$ has a dominant influence on the decision of students choose SMA Maitreyawira Batam, because it has the largest beta coefficient value is 0.414 and the largest tstatistics value is 4.776 .

3. Simultaneous Hypothesis Testing (Test F)

Test $\mathrm{F}$ aims to see whether all independent variables, namely reliability (X1), responsiveness (X2), assurance (X3), empathy (X4) and tangible (X5) in the model have a 
mutual influence on the dependent variable ie the decision to choose $(\mathrm{Y})$. This $\mathrm{F}$ test can be seen in Table 3 below:

Table 3 Hypothesis Testing Calculation Results (F test)

ANOVA $^{\mathrm{a}}$

\begin{tabular}{|rl|r|r|r|r|c|}
\hline Model & & Sum of Squares & \multicolumn{1}{c|}{ df } & Mean Square & F & Sig. \\
\hline \multirow{3}{*}{1} & Regression & 343.680 & 5 & 68.736 & 24.408 & $.000^{6}$ \\
& Residual & 292.875 & 104 & 2.816 & & \\
& Total & 636.555 & 109 & & & \\
\hline
\end{tabular}

a. Dependent Variable: Decision(Y)

b. Predictors: (Constant), Tangible(X5), Responsivenness(X2), Reliability(X1), Emphaty(X4), Assurance(X3)

Based on F test (table 5.23), it can be seen that the obtained Fhitung result of 24.408 is greater than Ftable (df regression 5; df residual 104) of 2.30. Since the Fcount value is greater than Ftable then this means Ho is rejected and H1 is accepted. It can be concluded that the quality of service which includes reliability (X1), responsiveness (X2), assurance (X3), empathy (X4) and tangible (X5) simultaneously have a significant influence on the decision of student choose SMA Maitreyawira.

Hypothesis testing can also be done by comparing the significance value of 0.000 smaller than the alpha $(\alpha)$ is 0.05 which means Ho is rejected and H1 accepted, so the independent variable reliability $(X 1)$, responsiveness $(X 2)$, assurance $(X 3)$ empathy $(X 4)$ and tangible (X5) simultaneously have a significant effect on the decision to vote (Y).

The regression test results simultaneously as in table 5.22 show that $\mathrm{R}$ Square (R2) is equal to 0,540 . This means that the contribution of the five independent variables to the dependent variable is $54.0 \%$, while the rest of $46.0 \%$ is influenced by other factors outside the research model.

Discussion of Research Results

1. Effect of Reliability (X1) on the Decision of Selecting

a. According to Parasuraman's theory, et al. (in Tjiptono, 2014) Reliability (reliability) is the ability to provide services promised immediately, accurately, and satisfactorily.

b. The results of previous research conducted by A Faiz Fadillah (2014), Thomas P.S and Liasta Ginting (2008), which states there is partially influence the variable reliability of the decision to vote. The results of previous research conducted by Iman Sumanto (2008) and Ratih Hardiyati (2010) which states there is partially influence the variable reliability to satisfaction.

c. Based on the partial test in this study, the variable reliability (X1) has a positive and significant effect on the decision of students to choose SMA Maitreyawira Batam, this can be seen from the results of t-test calculation as in table 5.24 that the obtained tstatistics of 2.114 and the result of ttable (df residual 104) is 1,982 , so it can be seen that tstatistics $(2,114)>$ ttable $(1,982)$ and significant value equal to $0,037<\alpha$ is 0,05 .

d. Conclusion: Ho is rejected and H1 accepted means reliability (X1) partially has a significant influence on the decision of student choice. The results of this study proves that the quality of service that is reliable, accurate and deftly done by the SMA Maitreyawira both from educators and educational staff and with no discriminating between one student with other students has brought a feeling of comfort and feel at home for students so it will bring the satisfaction influenced the decision of choosing Maitreyawira school.

2. The influence of responsiveness to the decision of choosing

a. According to Parasuraman's theory, et al. (in Tjiptono, 2014) Responsiveness (responsiveness) is the desire of the staff to help the customers and provide services with responsiveness. 
b. The results of previous research by A Faiz Fadillah (2014), Thomas P.S and Liasta Ginting (2008), which states there is partially influence the variable responsiveness to the decision to vote. The results of previous research conducted by Iman Sumanto (2008) and Ratih Hardiyati (2010) which states there is partially influence the variable responsiveness to satisfaction.

c. Based on the partial test in this study, the variable responsiveness (X2) has a positive and significant effect on the decision of students to choose SMA Maitreyawira Batam, this can be seen from the result of $t$ test as in Table 5.24 that the result of tstatistics obtained is 3,688 and the result of the ttable (df residual 104) of 1.982 , so it can be seen that tstatistics (3.688) $>$ ttable (1.982) and a significant value of $0.000<\alpha$ is 0.05 .

d. Conclusion: Ho is rejected and $\mathrm{H} 2$ accepted means responsiveness (X2) partially has a significant influence on the decision of student choice. This study proves that the quality of service with dimensions responsiveness applied by educators and education quickly responsive to student complaints, instill high confidence in the school and behave politely and kindly able to give influence to students in choosing SMA Maitreyawira. Responsiveness

3. The influence of assurance on the decision to vote

a. According to Parasuraman's theory, et al. (in Tjiptono, 2014) assurance is to include knowledge, competence, credibility, and credibility of staff, from harm, risk or doubt

b. The results of previous research conducted by A Faiz Fadillah (2014 which states there is the partial influence of assurance variables on the decision to vote.The results of previous research conducted by Iman Sumanto (2008) and Ratih Hardiyati (2010) which states there is partially influence the variable assurance to satisfaction.

c. Based on partial test in this research, it is found that assurance variable (X3) have positive and significant effect to student decision to choose SMA Maitreyawira Batam, this can be seen from tstatistics result obtained 4,776 and result from ttable (df residual 104) equal to 1,982 , so it can be seen that tstatistics $(4,776)>$ ttable $(1,982)$ and significant value $0.000<\alpha$ is 0,05 .

d. Conclusion: Ho is rejected and H3 accepted means Assurance (X3) partially has a significant influence on the student's decision to vote. This study proves that with the improvement of the quality of assurance that teachers have a competent knowledge capacity, teachers and staff able to instill ethics values to students and with the guarantee of SMA Maitreyawira have a good name and reputation in the eyes of society will be followed by increasing student satisfaction that brings impact to the decision of choosing to SMA Maitreyawira Batam.

4. The influence of Empathy on the decision to vote

a. According to Parasuraman's theory, et al. (in Tjiptono, 2014) Empathy (empathy) involves ease in relationships, good communication, personal attention and understanding of the individual needs of customers.

b. The results of previous research conducted by A Faiz Fadillah (2014) which states there is partially influence the empathy variable on the decision to vote. The results of previous research conducted by Iman Sumanto (2008) and Ratih Hardiyati (2010) which states there is partially influence the empathy variable on satisfaction.

c. Based on the partial test in this study obtained the result that the variable empathy (X4) has a positive and significant effect on the decision of students choose SMA Maitreyawira Batam, this can be seen tstatistics obtained by 3.050 and the result of ttable (df residual 104) of 1.982 , so it can be seen that tstatistics (3.050)> (1.982) and significant value of $0.003<\alpha$ is 0,05 . 
d. Conclusion: Ho is rejected and H4 accepted means empathy (X4) partially has a significant influence on the student's decision to vote. This research proves that the quality of service with empathy dimension done by all educator and high school student of Maitreyawira are able to comprehend student's comprehension, listening to students' complaints patiently and easily contacted when needed by students very influential on student decision in choosing SMA Maitreyawira Batam.

5. Tangible influence on the decision to vote

a. According to Parasuraman, et al. (in Tjiptono, 2014) Physical evidence (tangibles) includes facilities, equipment, personnel, and means of communication.

b. The results of research conducted by A Faiz Fadillah (2014) which states there is a partial influence tangible variable on the decision to vote. The results of previous research conducted by Iman Sumanto (2008) and Ratih Hardiyati (2010) which states there is partially influence the tangible variable on satisfaction.

c. Based on the partial test, the tangible variable (X5) has a positive and significant effect on the decision of students to choose SMA Maitreyawira Batam, this can be seen from the tstatistics obtained by 3.050 and the result of ttable (df residual 104) of 1.982 , can be seen that tstatistics (3.050) $>(1.982)$ and significant value of $0.003<\alpha$ that is 0,05 .

d. Conclusion: Ho is rejected and H5 accepted means tangible (X5) partially has a significant influence on the student's decision to vote. This study proves that the quality of service with tangible dimension is applied well in SMA Maitereyawira by providing having learning facilities, equipment, and room, communication facilities, as well as the number of educators and adequate education influence on the decision of students, choose SMA Maitreyawira Batam.

6. The dominant Assurance variable (Collateral) against the voting decision.

The results of this study resulted that the quality of service with assurance variables have a dominant significant influence on the decision of students choose SMA Maitreyawira Batam. This proves the service quality of assurance variables provided by SMA Maitreyawira Batam by having educators and educators with good knowledge and competence, service with the application of ethical values to students, schools of good reputation in society and service in creating a safe and comfortable atmosphere for students to be the most dominant selling point dominantly influence students' decision to choose SMA Maitreyawira Batam.

7. The seventh hypothesis in this study is the quality of service consisting of variable Reliability, Responsiveness, Assurance, Empathy and Tangible together or simultaneously affect the decision of students choose SMA Maitreyawira Batam.

Based on F Test analysis in this study indicates that the quality of service consisting of variable Reliability, Responsiveness, Assurance, Empathy and Tangible simultaneously or simultaneously have a significant influence on the decision of students choose SMA Maitreyawira Batam. This can be proven from the obtained Fhitung result of 24.408 greater than at Ftable (df regression 5; df residual 104) of 2.30. Since the value of Fcount is greater than Ftable and its significance value is 0,000 smaller than the alpha $(\alpha)$ which is 0.05 .

This research is in accordance with research conducted by Thomas PS and Liasta Ginting (2008) under the title of Analysis of Quality of Consumer Service Quality at Ucok Durian Iskandar Muda Medan to the Purchasing Decision, while the result of the research is based on simultaneous test, service quality consisting of evidence variable physical, reliability, responsiveness, assurance, and attention simultaneously or 
simultaneously have a positive and significant effect on the purchasing decision of Ucok Durian Iskandar Muda Medan.

\section{Conclusion}

Based on the results of research, data analysis and discussion that has been described previously, so that can be drawn conclusion as follows:

1. Partial influence of reliability on the decision of students to choose SMA Maitreyawira Batam. This shows hypothesis 1 which states that the quality of service with reliability variables significantly influence individually or partially to the decision of students to choose SMA Maitreyawira Batam is accepted.

2. There is partial influence responsiveness to decision of student choose SMA Maitreyawira Batam. This shows hypothesis 2 which states that the quality of service with variable responsiveness significantly influence individually or partially to the decision of students choose SMA Maitreyawira Batam is accepted.

3. There is partial influence of assurance on student decision to choose SMA Maitreyawira Batam. This shows hypothesis 3 which states that the quality of service with variable assurance have significant influence individually or partially to decision of student choose SMA Maitreyawira Batam is accepted.

4. There is partially empathy influence on decision of student choose SMA Maitreyawira Batam. This shows hypothesis 4 which states that the quality of service with empathy variables significantly influence individually or partially to the decision of students choose SMA Maitreyawira Batam is accepted.

5. There is a tangible partial influence on the decision of students to choose SMA Maitreyawira Batam. This shows the hypothesis 5 which states that the quality of service with direct evidence variables significantly influence individually or partially to the decision of students choose SMA Maitreyawira Batam is accepted.

6. Quality of service with assurance variable (guarantee) most dominant has an effect on significant to decision of student choose SMA Maitreyawira Batam.

7. There is influence simultaneously the quality of service with variable reliability, responsiveness, assurance, empathy and tangible to the decision of students choose SMA Maitreyawira Batam.

This shows the seventh hypothesis which states that the quality of service with variable reliability, responsiveness, assurance, empathy and tangible simultaneously or simultaneously have a significant effect on the decision of students to choose SMA Maitreyawira Batam is accepted.

\section{Reference}

Arisutha, Damartaji, 2005. Dimensi Kualitas Pelayanan. Penerbit Gramedia Pustaka, Jakarta. Budiyono. 2009. Statistik untuk penelitian (ed. ke-2). Surakarta: UNS Press.

Cahyono, 2003. Pemasaran, Pemasar dan Pelanggan. Penerbit Pustakajaya, Jakarta.

Dekker, A. Steven, 2001. Measure Service Quality: Reexamination and Extension. Journal of Marketing. Vol. 56. July, 55-68. (Translated by Sutanto).

Dermawan Wibisono,Ph.D,2006. Manajemen kinerja, Erlangga Surabaya.

Duwi Priyatno. (2010). Teknik mudah dan cepat melakukan analisis data penelitian dengan SPSS dan tanya jawab ujian pendadaran. Yogyakarta: Penerbit Gava Media.

Field, A. (2009). Discovering statistics using SPSS (3rd ed.). London: Sage Publications Ltd.

Fraenkel, J.R. \& Wallen, N.E. (1993). How to design and evaluate research in education (2nd ed.). New York: McGraw-Hill Inc. 
Gaspersz, Vincent, 2003. Manajemen Bisnis Total - Total Quality Management. Penerbit PT. Gramedia Pustaka Utama, Jakarta.

Ghurgen, Jacob, 2002. Marketing and Market Decision Making. Published by John Wiley and Sons, New York.

Gronroos, Michael, 1990. Perceived Service Quality Model. Published Ohio University Press, California.

Hesketts, Robert, 1990. Service Profit Chain Model. Prentice Hall, California Press.

Istijanto, 2005. Aplikasi Praktis Riset Pemasaran. PT Gramedia Pustaka Utama. Jakarta.

Kotler Philips dan Kevin Keller. 2010. Marketing 13th. Salemba Empat, Jakarta.

Kotler, Philip dan Gary Amstrong. 2008. Prinsip-Prinsip Pemasaran. Edisi 12 jilid Pertama. Jakarta: Penerbit Erlangga

M. Ma'ruf Abdullal, 2014. Manajemen dan Evaluasi Kinerja Karyawan. Penerbit Aswaja Pressindo, Yogyakarta

Margaretha 2003, kualitas pelayanan: teori dan aplikasi, Mandar Maju, Jakarta

Martul, Shadiqqin, 2004. Implementasi Dimensi Kualitas Pelayanan Konsumen. Penerbit Sinar Grafika,Jakarta.

Norman, Davis, 1992. Service Management System. Prentice Hall Ohio University Press, USA.

Parasuraman,A.Valerie,2001 (translated by sutanto) Delivering Quality Service, The Free Press, New York

Parasuraman, Berry L dan Zeithalm. 1988. Consumer Behaviour. McGraw-Hill, Irwin.

Peter, J.H., 2003. Service Management in Managing The Image. Trisakti University, Jakarta.

Ratih Hardiyati, 2010 melakukan penelitian dengan judul analisis pengaruh kualitas pelayanan terhadap kepuasan konsumen menggunakan jasa penginapan (villa) agrowisata, skripsi Universitas Diponegoro.

Samuelson, Jeniston, 2000. Application of Quality Service Theory. Published by John Wiley and Sons, USA.

Sangadji,E.M.,\& Sopiah. (2013). Perilaku konsumen: pendekatan praktis, ANDI, Yogyakarta

Sari Yakut Dekrita. 2012. Faktor-faktor yang Mempengaruhi Keputusan Menjadi Nasabah Asuransi AIG Bumiputra. Journal Manajemen Pemasaran Volume 3 Nomor 1. Universitas Gunadarma, Jakarta.

Situmorang, Syafrizal Helmi, Doli M. Ja'far Dalimunthe, Iskandar Muda, Muclish Lufti, dan Syahyunan, 2008. Analisis Data Penelitian (Menggunakan Program SPSS), USU Press, Medan.

Stemvelt, Robert C., 2004. (Translated by Purwoko) Perception of Service Quality. Allyn and Bacon, Massachusetts.

Sugiyono, 2004. Teknik Penarikan Sampel untuk Metodologi Penelitian Kuantitatif. Penerbit Remadja Rosdakarya, Jakarta.

Sugiyono, 2008. Metode Penelitian Bisnis, CV. Alfabeta, Bandung

Sugiyono. (2010). Statistika untuk penelitian. Bandung: Alfabeta.

Sunyoto, Haming Praja,2004. Jaminan Kualitas Pelayanan, Liberty, Yogyakarta

Taylor \& Baker, 1994. Oslen, 2002. Dalam Kotler Philips dan Kevin Keller. 2010. Marketing 13th. Salemba Empat, Jakarta.

Tjiptono Fandy. 1999. Strategi Pemasaran. Andi. Yogyakarta

Tjiptono, Fandy, 2008. Service Management: Mewujudkan Layanan Prima, Andi, Yogyakarta. Tjiptono, Fandy, 2014. Pemasaran jasa, Andi, Yogyakarta.

Thomas P.S dan Liasta Ginting 2008. Analisis Pengaruh Kualitas Pelayanan Konsumen pada Warung Ucok Durian Iskandar Muda Medan terhadap Keputusan Pembelian, FE USU 
Yong, C.Z., Yun, Y.W., Loh, L., 2003. (Diterjemahkan oleh Sutanto). The Quest for Global Quality. Pustaka Delapratasa, Jakarta.

Yulian Belinda Ambarwati 2010, Pengaruh Kualitas Pelayanan terhadap kepuasan nasabah di PT Bank Central Asia (BCA) Tbk cabang Undaan Surabaya, Tesis Universitas Narotama. 